\title{
Milk exosomes: beyond dietary microRNAs
}

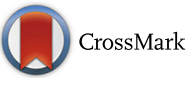

\author{
Janos Zempleni
}

\begin{abstract}
Extracellular vesicles deliver a variety of cargos to recipient cells, including the delivery of cargos in dietary vesicles from bovine milk to non-bovine species. The rate of discovery in this important line of research is slowed by a controversy whether the delivery and bioactivity of a single class of vesicle cargos, microRNAs, are real or not. This opinion paper argues that the evidence in support of the bioavailability of microRNAs encapsulated in dietary exosomes outweighs the evidence produced by scholars doubting that phenomenon is real. Importantly, this paper posits that the time is ripe to look beyond microRNA cargos and pursue innovative pathways through which dietary exosomes alter metabolism. Here, we highlight potentially fruitful lines of exploration.
\end{abstract}

Keywords: Exosomes, Extracellular vesicles, Milk

\section{Advancing the field of milk vesicles}

All multicellular and unicellular organisms communicate with their environment through extracellular vesicles (EVs) [1-4]. Healthy cells produce and secrete two major classes of EVs: exosomes are about $100 \mathrm{~nm}$ in size and are derived from endosomes in the multivesicular body; microvesicles are between 200 and $1000 \mathrm{~nm}$ in size and are formed by blebbing of the plasma membrane [4].

This paper focuses on exosomes due to their essential roles in cell-to-cell communication through shuttling a variety of cargos among tissues [1, 5-9]. Exosomes and their cargos have been implicated in virtually all physiological and pathological conditions [10-18]. Cargos include various species of coding and non-coding RNAs, proteins, and lipids [8, 19-22]. The loading of exosomes with cargos is not a random process but involves sorting mechanisms that favor some cargos over others $[21,23,24]$. Exosomes may deliver their cargos over short distances to receptor cells adjacent to the exosome-secreting donor cell, or cargos may be delivered to receptor cells in distant tissues $[1,8,9,11,25]$.

Evidence suggests that exosomes and their cargos are not only derived from endogenous synthesis but can also be obtained from dietary sources, particularly bovine and human milk. Milk exosomes are of particular interest because they constitute a scalable source of exosomes for drug loading and delivery (bovine), the

Correspondence: jzempleni2@unl.edu

Department of Nutrition and Health Sciences, University of Nebraska-Lincoln, Lincoln, NE, USA essential role of (human) milk in infant nutrition, and the large volume of (bovine) milk and other dairy consumed by Americans [26, 27]. This paper has a focus on the biological activity of exosomes and their cargos from bovine milk in non-bovine species but also discusses other dietary sources of exosomes where appropriate.

Bovine milk exosomes enter human and rat intestinal cells and human endothelial cells by endocytosis $[28,29]$, enter circulating immune cells [20], and accumulate in peripheral tissues $[26,30]$. A report that bovine milk exosomes can be detected in virtually all peripheral tissues was based on studies that lacked vehicle controls [26]; the widespread distribution of bovine milk exosomes among tissues in non-bovine species awaits confirmation. Prime candidates are tissues rich in resident immune cells such as liver, spleen and lung, and the site of absorption in the small intestine [30-33]. Encapsulation of labile cargos in exosomes confers a mechanism of protection against harsh conditions in the intestinal tract such as low $\mathrm{pH}$ in the stomach and against exposure to enzymes such as RNases and proteases [34, 35]. Collectively, it is possible that milk exosomes deliver bioactive cargos to hosts following oral administration.

Unfortunately, the rate of discovery in the field of dietary exosomes and their cargos has been slowed down by a continuing controversy whether a particular class of cargos, microRNAs, is delivered across species boundaries and elicit biological effects, or dietary microRNAs in body fluids are too low to elicit effects or might be assay artifacts (reviewed in [36]). These discussions are 
ongoing and, in the author's opinion, have not lead to a satisfactory resolution of the dispute whether dietary microRNAs have biological activity. The author proposes that momentum is building in support of the theory that dietary microRNAs are bioavailable and alter gene expression across species boundaries, based on reports from a large number of independent laboratories including ours [37-50]. Strong arguments in favor of the bioavailability of dietary RNAs include the following. (1) Exogenous microRNAs were detected by RNA sequencing (RNA-seq) in human plasma and breast milk [38-40]. (2) There is consensus that bovine milk exosomes are bioavailable [26, 28-30, 33]. (3) Feeding a diet depleted of bovine milk exosomes and microRNAs caused a more than $60 \%$ decrease in plasma microRNAs compared with controls [39]. (4) Some genetically modified organisms utilize synthetic microRNA analogs, small interfering RNAs (siRNAs), to achieve gene knockdown in pests [51] (e.g., DvSnf7 siRNA in Monsanto's Smart Stax Pro corn; [52]. The siRNAs in these organisms are biologically active (i.e., kill pests upon absorption). (5) RNAs encapsulated in bovine milk exosomes survive harsh conditions such as low $\mathrm{pH}$ [34] and digestion under simulated gastrointestinal tract conditions [35].

Some critical voices remain. Concerns were raised regarding "ineffective microRNA delivery of oral microRNAs" and the possibility of sample contamination [53-55]. One of these reports was based on the analysis of samples in which the dry ice was sublimated during shipping to the investigators' laboratory and therefore should be discounted [56]. Title et al. employed an interesting cross-fostering strategy and detected only trace amounts of miR-375 in the plasma of miR-375 knockout pups fostered to wild-type dams [55]. The authors disregarded the possibility that, upon intestinal absorption, miR-375 binds to transcript targets in the intestinal mucosa and liver, followed by rapid degradation (the classical "first passage elimination" effect), which is consistent with miRNA "sponge" use in microRNA research $[57,58]$, and our observation that the majority of milk exosomes accumulate in the intestinal mucosa and liver [30,33]. Title et al. could not have been aware of a later report that the sequence motif, $(\mathrm{A} / \mathrm{U})\left(\mathrm{C}_{2-4}\right)(\mathrm{A} / \mathrm{U})$, is essential for miRNA packaging into exosomes [59]; the motif is missing in miR-375 although other motifs might exist.

We propose that while these somewhat myopic deliberations continue, the field of dietary exosomes needs to explore new pathways by which dietary exosomes may elicit phenotypes. Here, we highlight a few examples. First, a substantial portion of exosomes in bovine milk escapes absorption and enters the large intestine [30]. When considering that microorganisms communicate with their environment through EVs [3], it would be worthwhile to study the effects of dietary EV intake on the gut microbiome. Our preliminary data suggest that feeding a diet deplete of vesicles from bovine milk causes changes in the gut microbiome in mice [60]. Second, exosomes contain a variety of bioactive lipids, proteins, and non-coding RNAs other than microRNAs $[8,19-22]$. Evidence is emerging that exosomes may deliver some of these compounds to target tissues [61]. Third, RNAs including microRNAs may bind to Tolllike receptors to regulate immune responses [62]. It may be worthwhile to explore whether RNAs in milk exosomes also bind to Toll-like receptors. Fourth, there is the possibility that the mere interactions of exosome with the cell surface may alter metabolism, as proposed by Askenase and co-workers [9]. Finally, we caution against making the assumption that milk exosomes and their cargos will necessarily travel to the same destination. Our ongoing studies suggest that bovine milk exosomes and their RNA cargos travel to distinct tissues [33]. Analytical preparations of exosomes and microvesicles may be contaminated with other classes of EVs or contain sub-populations from the same class of EVs with distinct biological functions [63]. Investigators need to examine protocols used for vesicle preparations to assess the identity of vesicles in a given study and the levels of rigors applied by them [6].

Studies of milk vesicles and their roles in human metabolism are an exciting line of research. We hope that the exploration of new pathways will rapidly advance this line of research in the future. This will not only be important for human nutrition but also for the delivery of drugs by bovine milk exosomes [26]. It will be important not to lose sight of the tremendous potential of dietary exosomes in the light of the sweltering controversy surrounding their microRNA cargos.

\section{Abbreviations \\ EVs: Extracellular vesicles}

\section{Funding}

This material is based upon the work that is supported by the National Institute of Food and Agriculture (NIFA), US Department of Agriculture, under award number 2015-67017-23181, NIH grant 1P20GM104320, and NIFA 2016-67001-25301/NIH R01 DK107264, the Gerber Foundation, the Egg Nutrition Center, USDA Hatch-1011996, and USDA multistate group W3002. The funding bodies played no role in the design of the study and collection, analysis, and interpretation of data and in writing the manuscript.

\section{Availability of data and materials}

Not applicable.

\section{Author's contributions \\ JZ conceived and wrote the manuscript. He read and approved the final manuscript.}

\section{Competing interests}

The author serves as consultant for PureTech Health, Inc. (Boston, MA). PureTech Health played no role in the design of the study and collection, analysis, and interpretation of data and in writing the manuscript. 


\section{Consent for publication}

Not applicable.

\section{Ethics approval and consent to participate}

Not applicable.

\section{Publisher's Note}

Springer Nature remains neutral with regard to jurisdictional claims in published maps and institutional affiliations.

Received: 22 February 2017 Accepted: 19 April 2017

Published online: 22 June 2017

\section{References}

1. Mittelbrunn M, Sanchez-Madrid F. Intercellular communication: diverse structures for exchange of genetic information. Nat Rev Mol Cell Biol. 2012; 13(5):328-35. doi:10.1038/nrm3335. Epub 2012/04/19. PubMed PMID: 22510790; PMCID: 3738855

2. Dormann P, Kim H, Ott T, Schulze-Lefert P, Trujillo M, Wewer $V$, Huckelhoven R. Cell-autonomous defense, re-organization and trafficking of membranes in plant-microbe interactions. New Phytol. 2014;204(4):815-22 doi:10.1111/nph.12978

3. Wolf JM, Casadevall A. Challenges posed by extracellular vesicles from eukaryotic microbes. Curr Opin Microbiol. 2014;22C:73-8. doi:10.1016/j.mib. 2014.09.012

4. Yanez-Mo M, Siljander PR, Andreu Z, Zavec AB, Borras FE, Buzas El, Buzas K, Casal E, Cappello F, Carvalho J, Colas E, Cordeiro-da Silva A, Fais S, FalconPerez JM, Ghobrial IM, Giebel B, Gimona M, Graner M, Gursel I, Gursel M, Heegaard NH, Hendrix A, Kierulf P, Kokubun K, Kosanovic M, Kralj-lglic V, Kramer-Albers EM, Laitinen $\mathrm{S}$, Lasser $\mathrm{C}$, Lener T, Ligeti $\mathrm{E}$, Line A, Lipps $\mathrm{G}$, Llorente A, Lotvall J, Mancek-Keber M, Marcilla A, Mittelbrunn M, Nazarenko I, Nolte-'t Hoen EN, Nyman TA, O'Driscoll L, Olivan M, Oliveira C, Pallinger E, Del Portillo HA, Reventos J, Rigau M, Rohde E, Sammar M, Sanchez-Madrid F, Santarem N, Schallmoser K, Ostenfeld MS, Stoorvogel W, Stukelj R, Van der Grein SG, Vasconcelos MH, Wauben MH, De Wever O. Biological properties of extracellular vesicles and their physiological functions. J Extracell Vesicles. 2015;4:27066. doi:10.3402/jev.v4.27066. PubMed PMID: 25979354; PMCID: PMC4433489.

5. Colombo M, Raposo G, Thery C. Biogenesis, secretion, and intercellular interactions of exosomes and other extracellular vesicles. Ann Rev Cell Develop Biol. 2014;30:255-89. doi:10.1146/annurev-cellbio-101512-122326. Epub 2014/10/08.

6. Lotvall J, Hill AF, Hochberg F, Buzas El, Di Vizio D, Gardiner C, Gho YS, Kurochkin IV, Mathivanan S, Quesenberry P, Sahoo S, Tahara H, Wauben MH, Witwer KW, Thery C. Minimal experimental requirements for definition of extracellular vesicles and their functions: a position statement from the International Society for Extracellular Vesicles. J Extracell Vesicles. 2014;3: 26913. doi:10.3402/jev.v3.26913. Epub 2014/12/30. PubMed PMID: 25536934; PMCID: 4275645

7. Andaloussi SEL, Mager I, Breakefield XO, Wood MJ. Extracellular vesicles: biology and emerging therapeutic opportunities. Nat Rev Drug Discov. 2013;12(5):347-57. doi:10.1038/nrd3978.

8. Raposo G, Stoorvogel W. Extracellular vesicles: exosomes, microvesicles, and friends. J Cell Biol. 2013;200(4):373-83. doi:10.1083/jcb.201211138. PubMed PMID: 23420871; PMCID: 3575529.

9. Bryniarski K, Ptak W, Martin E, Nazimek K, Szczepanik M, Sanak M, Askenase PW. Free extracellular miRNA functionally targets cells by transfecting exosomes from their companion cells. PLoS One. 2015;10(4):e0122991. doi: 10.1371/journal.pone.0122991. PubMed PMID: 25923429: PMCID: 4414541.

10. Bellingham SA, Guo BB, Coleman BM, Hill AF. Exosomes: vehicles for the transfer of toxic proteins associated with neurodegenerative diseases? Front Physiol. 2012;3:124. doi:10.3389/fphys.2012.00124. PubMed PMID: 22563321; PMCID: PMC3342525.

11. Vella LJ, Hill AF, Cheng L. Focus on extracellular vesicles: exosomes and their role in protein trafficking and biomarker potential in Alzheimer's and Parkinson's disease. Int J Mol Sci. 2016;17(2). doi: 10.3390/ijms17020173. PubMed PMID: 26861304; PMCID: PMC4783907.

12. Verma M, Lam TK, Hebert E, Divi RL. Extracellular vesicles: potential applications in cancer diagnosis, prognosis, and epidemiology. BMC Clin Pathol. 2015;15:6. doi:10.1186/s12907-015-0005-5. PubMed PMID: 25883534; PMCID: PMC4399158.
13. Taylor DD, Gercel-Taylor C. Exosome platform for diagnosis and monitoring of traumatic brain injury. Philos Trans R Soc Lond B Biol Sci. 2014;369(1652). doi: 10.1098/rstb.2013.0503. PubMed PMID: 25135964; PMCID: PMC4142024.

14. Thery C, Ostrowski M, Segura E. Membrane vesicles as conveyors of immune responses. Nat Rev Immunol. 2009;9(8):581-93. doi:10.1038/nri2567. Epub 2009/06/06

15. Robbins PD, Morelli AE. Regulation of immune responses by extracellular vesicles. Nat Rev Immunol. 2014;14(3):195-208. doi:10.1038/nri3622. PubMed PMID: 24566916; PMCID: PMC4350779.

16. Koeck ES, lordanskaia T, Sevilla S, Ferrante SC, Hubal MJ, Freishtat RJ, Nadler EP. Adipocyte exosomes induce transforming growth factor beta pathway dysregulation in hepatocytes: a novel paradigm for obesity-related liver disease. J Surg Res. 2014;192(2):268-75. doi:10.1016/j.jss.2014.06.050.

17. Vojtech L, Woo S, Hughes S, Levy C, Ballweber L, Sauteraud RP, Strobl J, Westerberg K, Gottardo R, Tewari M, Hladik F. Exosomes in human semen carry a distinctive repertoire of small non-coding RNAs with potential regulatory functions. Nucleic Acids Res. 2014;42(11):7290-304. doi:10.1093/ nar/gku347. PubMed PMID: 24838567; PMCID: 4066774

18. Danielson KM, Das S. Extracellular vesicles in heart disease: excitement for the future? Exosomes Microvesicles. 2014;2:1. doi:10.5772/58390. PubMed PMID: 25429310; PMCID: 4242103

19. Huang $X$, Yuan T, Tschannen M, Sun Z, Jacob H, Du M, Liang M, Dittmar RL, Liu Y, Liang M, Kohli M, Thibodeau SN, Boardman L, Wang L.

Characterization of human plasma-derived exosomal RNAs by deep sequencing. BMC Genomics. 2013;14:319. doi:10.1186/1471-2164-14-319. Epub 2013/05/15. PubMed PMID: 23663360; PMCID: 3653748.

20. Izumi H, Tsuda M, Sato Y, Kosaka N, Ochiya T, Iwamoto H, Namba K, Takeda Y. Bovine milk exosomes contain microRNA and mRNA and are taken up by human macrophages. J Dairy Sci. 2015;98(5):2920-33. doi:10.3168/jds.2014-9076.

21. Abels ER, Breakefield XO. Introduction to extracellular vesicles: biogenesis, RNA cargo selection, content, release, and uptake. Cell Mol Neurobiol. 2016; 36:301. doi:10.1007/s10571-016-0366-z.

22. Freedman JE, Gerstein M, Mick E, Rozowsky J, Levy D, Kitchen R, Das S, Shah R, Danielson K, Beaulieu L, Navarro FC, Wang Y, Galeev TR, Holman A, Kwong RY, Murthy V, Tanriverdi SE, Koupenova-Zamor M, Mikhalev E, Tanriverdi K. Diverse human extracellular RNAs are widely detected in human plasma. Nat Commun. 2016;7:11106. doi:10.1038/ncomms11106. PubMed PMID: 27112789; PMCID: PMC4853467.

23. Squadrito ML, Baer C, Burdet F, Maderna C, Gilfillan GD, Lyle R, Ibberson M, De Palma M. Endogenous RNAs modulate microRNA sorting to exosomes and transfer to acceptor cells. Cell Rep. 2014;8(5):1432-46. doi:10.1016/j. celrep.2014.07.035.

24. Stevanato L, Thanabalasundaram L, Vysokov N, Sinden JD. Investigation of content, stoichiometry and transfer of miRNA from human neural stem cell line derived exosomes. PLoS One. 2016;11(1):e0146353. doi:10.1371/journal. pone.0146353. PubMed PMID: 26752061; PMCID: 4713432.

25. Braicu C, Tomuleasa C, Monroig P, Cucuianu A, Berindan-Neagoe I, Calin GA Exosomes as divine messengers: are they the Hermes of modern molecular oncology? Cell Death Differ. 2015;22(1):34-45. doi:10.1038/cdd.2014.130. PubMed PMID: 25236394; PMCID: PMC4262777.

26. Munagala R, Aqil F, Jeyabalan J, Gupta RC. Bovine milk-derived exosomes for drug delivery. Cancer Lett. 2016;371(1):48-61. doi:10.1016/j.canlet.2015. 10.020. PubMed PMID: 26604130; PMCID: 4706492.

27. United States Department of Agriculture. Dairy Data [Internet] 1975 [cited 10/21/2013]. Available from: http://www.ers.usda.gov/data-products/dairydata.aspx\#.UmVuAmwo5aQ.

28. Wolf T, Baier SR, Zempleni J. The intestinal transport of bovine milk exosomes is mediated by endocytosis in human colon carcinoma caco-2 cells and rat small intestinal IEC-6 cells. J Nutr. 2015;145:2201-6. doi:10.3945/ jn.115.218586. PubMed PMID: 26269243; PMCID: 4580964

29. Kusuma Jati R, Manca S, Friemel T, Sukreet S, Nguyen C, Zempleni J. Human vascular endothelial cells transport foreign exosomes from cow's milk by endocytosis. Am J Physiol Cell Physiol. 2016;310:C800-7. PubMed PMID: 26984735; PMCID: 4895447.

30. Manca S, Giraud D, Zempleni J. Bioavailability and biodistribution of fluorophore-labeled exosomes from cow's milk after intravenous and oral administration in C57BI/6J mice. FASEB J. 2016;30(supplement 1):690. 8.

31. Takahashi $Y$, Nishikawa M, Shinotsuka H, Matsui $Y$, Ohara S, Imai T, Takakura $Y$. Visualization and in vivo tracking of the exosomes of murine melanoma B16-BL6 cells in mice after intravenous injection. J Biotechnol. 2013;165(2): 77-84. doi:10.1016/j.jbiotec.2013.03.013. Epub 2013/04/09. 
32. Imai T, Takahashi Y, Nishikawa M, Kato K, Morishita M, Yamashita T, Matsumoto A, Charoenviriyakul C, Takakura Y. Macrophage-dependent clearance of systemically administered B16BL6-derived exosomes from the blood circulation in mice. J Extracell Vesicles. 2015;4:26238. doi:10.3402/jev. v4.26238. PubMed PMID: 25669322; PMCID: 4323410.

33. Manca S, Giraud D, Zempleni J, editors. The bioavailability and distribution of bovine milk exosomes is distinct from that of their cargos in mice. FASEB J. 2017 (peer-reviewed meeting abstract, in press).

34. Izumi H, Kosaka N, Shimizu T, Sekine K, Ochiya T, Takase M. Bovine milk contains microRNA and messenger RNA that are stable under degradative conditions. J Dairy Sci. 2012;95(9):4831-41. doi:10.3168/jds.2012-5489. Epub 2012/08/25

35. Benmoussa A, Lee CH, Laffont B, Savard P, Laugier J, Boilard E, Gilbert C, Fliss I, Provost P. Commercial dairy cow milk microRNAs resist digestion under simulated gastrointestinal tract conditions. J Nutr. 2016;146(11):220615. doi:10.3945/jn.116.237651. Epub 2016/11/03.

36. Zempleni J, Aguilar-Lozano A, Sadri M, Sukreet S, Manca S, Wu D, Zhou F, Mutai E. Biological activities of extracellular vesicles and their cargos from bovine and human milk in humans and implications for infants. J Nutr. 2016;147:3-10. doi:10.3945/jn.116.238949.

37. Zhang L, Hou D, Chen X, Li D, Zhu L, Zhang Y, Li J, Bian Z, Liang X, Cai X, Yin Y, Wang C, Zhang T, Zhu D, Zhang D, Xu J, Chen Q, Ba Y, Liu J, Wang Q, Chen J, Wang J, Wang M, Zhang Q, Zhang J, Zen K, Zhang CY. Exogenous plant MIR168a specifically targets mammalian LDLRAP1: evidence of crosskingdom regulation by microRNA. Cell Res. 2012;22(1):107-26. doi:10.1038/ cr.2011.158. Epub 2011/09/21. PubMed PMID: 21931358; PMCID: 3351925.

38. Wang K, Li H, Yuan Y, Etheridge A, Zhou Y, Huang D, Wilmes P, Galas D. The complex exogenous RNA spectra in human plasma: an interface with human gut biota? PLoS One. 2012;7(12):e51009. doi:10.1371/journal.pone. 0051009. Epub 2012/12/20. PubMed PMID: 23251414; PMCID: 3519536.

39. Baier SR, Nguyen C, Xie F, Wood JR, Zempleni J. MicroRNAs are absorbed in biologically meaningful amounts from nutritionally relevant doses of cow's milk and affect gene expression in peripheral blood mononuclear cells, HEK-293 kidney cell cultures, and mouse livers. J Nutr. 2014:144:1495-500. PubMed PMID: 25122645; PMCID: 4162473.

40. Lukasik A, Zielenkiewicz P. In silico identification of plant miRNAs in mammalian breast milk exosomes—a small step forward? PLoS One. 2014 9(6):e99963. doi:10.1371/journal.pone.0099963. PubMed PMID: 24933019; PMCID: 4059707

41. Beatty M, Guduric-Fuchs J, Brown E, Bridgett S, Chakravarthy U, Hogg RE, Simpson DA. Small RNAs from plants, bacteria and fungi within the order Hypocreales are ubiquitous in human plasma. BMC Genomics. 2014;15:933. doi:10.1186/1471-2164-15-933. PubMed PMID: 25344700; PMCID: 4230795.

42. Liang G, Zhu Y, Sun B, Shao Y, Jing A, Wang J, Xiao Z. Assessing the survival of exogenous plant microRNA in mice. Food Sci Nutr. 2014;2(4):380-8. doi: 10.1002/fsn3.113. PubMed PMID: 25473495; PMCID: 4221836.

43. Yang J, Farmer LM, Agyekum AA, Hirschi KD. Detection of dietary plantbased small RNAs in animals. Cell Res. 2015;25(4):517-20. doi:10.1038/cr. 2015.26. Epub 2015/02/28. PubMed PMID: 25721324; PMCID: 4387557.

44. Ju S, Mu J, Dokland T, Zhuang X, Wang Q, Jiang H, Xiang X, Deng ZB, Wang B, Zhang L, Roth M, Welti R, Mobley J, Jun Y, Miller D, Zhang HG. Grape exosome-like nanoparticles induce intestinal stem cells and protect mice from DSS-induced colitis. Mol Ther. 2013;21(7):1345-57. doi:10.1038/mt.2013. 64. PubMed PMID: 23752315; PMCID: 3702113

45. Mu J, Zhuang $X$, Wang $Q$, Jiang $H$, Deng ZB, Wang B, Zhang L, Kakar S, Jun $Y$, Miller D, Zhang HG. Interspecies communication between plant and mouse gut host cells through edible plant derived exosome-like nanoparticles. Mol Nutr Food Res. 2014;58(7):1561-73. doi:10.1002/mnfr. 201300729.

46. Mlotshwa S, Pruss GJ, MacArthur JL, Endres MW, Davis C, Hofseth L, Pena MM, Vance $V$. A novel chemopreventive strategy based on therapeutic microRNAs produced in plants. Cell Res. 2015;25(4):521-4. doi:10.1038/cr. 2015.25. PubMed PMID: 25721325; PMCID: 4387556.

47. Chin AR, Fong MY, Somlo G, Wu J, Swiderski P, Wu X, Wang SE. Crosskingdom inhibition of breast cancer growth by plant miR159. Cell Res. 2016; 26(2):217-28. doi:10.1038/cr.2016.13. PubMed PMID: 26794868; PMCID: 4746606.

48. Zhou Z, Li X, Liu J, Dong L, Chen Q, Liu J, Kong H, Zhang Q, Qi X, Hou D, Zhang L, Zhang G, Liu Y, Zhang Y, Li J, Wang J, Chen X, Wang H, Zhang J, Chen H, Zen K, Zhang CY. Honeysuckle-encoded atypical microRNA2911 directly targets influenza A viruses. Cell Res. 2015;25:39-49. doi:10.1038/cr. 2014.130. PubMed PMID: 25287280; PMCID: 4650580

49. Chen X, Dai GH, Ren ZM, Tong YL, Yang F, Zhu YQ. Identification of dietetically absorbed rapeseed (Brassica campestris L.) bee pollen microRNAs in serum of mice. Biomed Res Int. 2016;2016:5413849. doi:10.1155/2016/ 5413849. PubMed PMID: 27597967; PMCID: PMC5002473.

50. Cavalieri D, Rizzetto L, Tocci N, Rivero D, Asquini E, Si-Ammour A, Bonechi E, Ballerini C, Viola R. Plant microRNAs as novel immunomodulatory agents. SC Rep. 2016:6:25761. doi:10.1038/srep25761.

51. Heinemann JA, Agapito-Tenfen SZ, Carman JA. A comparative evaluation of the regulation of GM crops or products containing dsRNA and suggested improvements to risk assessments. Environ Int. 2013;55:43-55. doi:10.1016/j. envint.2013.02.010.

52. Monsanto, Inc. Petition for determination of nonregulated status for corn rootworm protected and glyphosate tolerant MON 87411 Maize. St. Louis: USDA APHIS; 2013. p. 290-1.

53. Snow JW, Hale AE, Isaacs SK, Baggish AL, Chan SY. Ineffective delivery of diet-derived microRNAs to recipient animal organisms. RNA Biol. 2013;10(7): 1107-16. doi:10.4161/rna.24909. Epub 2013/05/15. PubMed PMID: 23669076; PMCID: 3849158.

54. Dickinson B, Zhang Y, Petrick JS, Heck G, Ivashuta S, Marshall WS. Lack of detectable oral bioavailability of plant microRNAs after feeding in mice. Nat Biotechnol. 2013;31(11):965-7. doi:10.1038/nbt.2737. Epub 2013/11/12.

55. Title AC, Denzler R, Stoffel M. Uptake and function studies of maternal milkderived microRNAs. J Biol Chem. 2015;290(39):23680-91. doi:10.1074/jbc. M115.676734. PubMed PMID: 26240150; PMCID: 4583031.

56. Auerbach A, Vyas G, Li A, Halushka M, Witwer K. Uptake of dietary milk miRNAs by adult humans: a validation study. F1000Res. 2016;5:721. doi:10. 12688/f1000research.8548.1. PubMed PMID: 27158459; PMCID: PMC4857747.

57. Pond SM, Tozer TN. First-pass elimination. Basic concepts and clinical consequences. Clin Pharmacokinet. 1984;9(1):1-25. doi:10.2165/00003088198409010-00001.

58. Ebert MS, Neilson JR, Sharp PA. MicroRNA sponges: competitive inhibitors of small RNAs in mammalian cells. Nat Methods. 2007;4(9):721-6. doi:10.1038/ nmeth1079. PubMed PMID: 17694064; PMCID: 3857099.

59. Shurtleff M. Cell-free packaging of microRNAs into exosomes reveals Y-box protein I as a critical sorting factor. Annual meeting of the American Society for Cell Biology; San Diego:2015 (peer-reviewed meeting abstract).

60. Zhou F, Paz AH, Sadri M, Fernando CS, Zempleni J. A diet defined by its content of bovine milk exosomes alters the composition of the intestinal microbiome in C57BL/6 mice. FASEB J. 2017 (peer-reviewed meeting abstract, in press)

61. Yim N, Ryu SW, Choi K, Lee KR, Lee S, Choi H, Kim J, Shaker MR, Sun W, Park $\mathrm{JH}$, Kim D, Heo WD, Choi C. Exosome engineering for efficient intracellular delivery of soluble proteins using optically reversible protein-protein interaction module. Nat Commun. 2016;7:12277. doi:10.1038/ncomms12277. PubMed PMID: 27447450; PMCID: PMC4961865.

62. Fabbri M, Paone A, Calore F, Galli R, Gaudio E, Santhanam R, Lovat F, Fadda P, Mao C, Nuovo GJ, Zanesi N, Crawford M, Ozer GH, Wernicke D, Alder H, Caligiuri MA, Nana-Sinkam P, Perrotti D, Croce CM. MicroRNAs bind to Tolllike receptors to induce prometastatic inflammatory response. Proc Natl Acad Sci U S A. 2012;109(31):E2110-6. doi:10.1073/pnas.1209414109. PubMed PMID: 22753494; PMCID: 3412003.

63. Tauro BJ, Greening DW, Mathias RA, Mathivanan S, Ji H, Simpson RJ. Two distinct populations of exosomes are released from LIM1863 colon carcinoma cell-derived organoids. Mol Cell Proteomics. 2013;12(3):587-98. doi:10.1074/mcp.M112.021303. PubMed PMID: 23230278; PMCID: 3591653. 